Journal of Urban and Regional Analysis, vol. XIII, 1, 2021, p. 59 - 75

https://doi.org/10.37043/JURA.2021.13.1.4

\title{
APPLICATION OF A FUZZY SYSTEM TO THE ANALYSIS OF ENTREPRENEURIAL INTENTION IN COLOMBIA
}

\author{
Juan Manuel ARISTIZÁBAL ${ }^{1}$, Edwin TARAPUEZ ${ }^{2}$, Beatriz GUZMÁN ${ }^{2}$ \\ ${ }^{1}$ Universidad de Manizales, Manizales, Colombia \\ ${ }^{2}$ Universidad del Quindío, Armenia, Colombia
}

\begin{abstract}
The incidence of diverse factors on the intention to create enterprises (EI) motivates the calculation of a multidimensional indicator that groups the initial endowments of the individual and the characteristics of the environment. Thus, the research introduces a new way of measuring business intent based on the mathematical support of the theory of fuzzy sets; thus, employing a sample of MBA students in Colombia, a Multidimensional Index of Enterprise Intent (MIEI) was calculated for 14 cities, segmented by gender, age, and area of studies. The results of the document expose heterogeneity in Colombian cities in terms of El, with greater development in spatial units with facilities to do business. Particularly, the results denote the presence of an El cycle in the age range between 30 and 40 years and they confirm Bogotá, D.C., as the city with the highest El in Colombia. Meanwhile, the findings confirm minor entrepreneurial development in students with vocation for agricultural science.
\end{abstract}

Key Words: fuzzy sets, entrepreneurship, business intent, entrepreneurial intention, entrepreneurship index.

\section{Introduction}

Within the current context, according to the Global Entrepreneurship Monitor Colombia (2019), entrepreneurship has become a basic tool for job creation and wealth generation (BarbaSánchez and Atienza-Sahuquillo 2017); likewise, empirical evaluations have shown that economic growth and development are linked to business spirit (Oosterbeek et al. 2010). Thus, entrepreneurship, as research theme, gains importance in understanding a field of action that permits potentiating opportunities of regional development to promote technological progress, generate jobs, increase added value, and enhance local economies, among other aspects (Ferreira et al. 2019). Nevertheless, for Colombia, less empirical evidence exists in relation to the transmission mechanism exerted by environmental factors on the development of entrepreneurial initiatives in cases applied in students.

Considering the aforementioned, understanding learning processes, innovation, and business spirit are at the core of economic analysis. Nevertheless, the multiplicity of variables that influence El hinders its parameterization. Thus, the transversality that encompasses the El concept, added to the pertinence of grouping it into a multidimensional indicator, configure the central object of this research. In this sense, a fuzzy inference system is proposed as mathematical support to construct a Multidimensional Index of Entrepreneurial Intention (MIEI) in MBA students in Colombia. Particularly, in the El study, the theory of fuzzy sets is pertinent and appropriate, given that it relaxes the weighting of objective and subjective characteristics.

In spite of its relevance, few works truly define what El is; however, some authors, like Thompson (2009), assume that El is a self-recognized conviction by an individual who seeks to create a business and undertakes a conscious planning process to reach the said purpose at some point in life. Additionally, for Peng et al. (2012), El is the mental orientation, desire, and hope that intervene in the election of a specific entrepreneurial initiative. Bird (1988) assumes 
that El concerns a necessary and prior process carried out before conducting a given enterprise action; a definition complemented by Baum et al. (2007), who go a bit further when considering that enterprise creation is the result of an intentional behavior.

Consequently, this document contributes to the literature on entrepreneurial spirit from two settings. In the first place, the study supports the empirical evidence in relation with regional heterogeneity and the difference in El for the case of Colombian cities. Secondly, the proposed empirical strategy captures the effect of the environment through institutional and macroeconomic characteristics on EI in the group of students. In this case, the social and institutional environment is a key component in the development of El (Kallas 2019). Finally, the research provides empirical evidence on the regional differences in El in Colombia.

With the aforementioned idea exposed, the use of the theory of fuzzy sets in the field of study of entrepreneurship is brief; nevertheless, as of 2013, there has been increased applied research with empirical strategy based on the mathematical support provided by the fuzzy logic; among them, Cheng et al. (2013), Covin et al. (2016), Kraus et al. (2016), and Kraus et al. (2018). For this purpose, an empirical study was conducted among 477 students distributed in 16 MBA programs in Colombia, in 14 cities. Particularly, a multidimensional index was designed for different characteristics of the population and cities. As mentioned, the index is based on the concepts of fuzzy logic. Thus, the study results permit the establishing of three conclusions. First, according to the level of student privation in reference with the considered attributes, the family and institutional dimensions have greater relevance in estimating the index; second, the cities of Bogotá D.C. and Popayán report the highest El. Finally, in the analysis by gender and age, the MIEI exposes a higher value for the male students and in the group between 30 and 40 years of age.

Internationally, some indices exist to measure certain aspects related with entrepreneurship, among them: the Global Entrepreneurship Monitor Colombia (2019) by the Babson College, Doing Business (DB) by the World Bank, the Flash Eurobarometer Survey on Entrepreneurship by the European Commission, the Global University Entrepreneurial Spirit Students' Survey (GUESSS) by the University of Saint Gallen in Switzerland, the International Observatory of Entrepreneurial Intentions of University Students (OI2E2) by University Pierre Mendès France in France, the Global Entrepreneurship and Development Index (GEDI) from the Global Institute on Entrepreneurship and Development, the Index of Systemic Conditions for Dynamic Entrepreneurship (ISCDE), and the Index of Systemic Conditions for Entrepreneurship in Cities (ICEC) by the Entrepreneur Development Program (PRODEM, Argentina), and the AEI Index by Universidad Andina Simón Bolívar in Ecuador.

The Global Entrepreneurship Monitor Colombia studies the behavior of individuals at the start up and management of a business. Its objective is to measure the differences in entrepreneurship among the participating nations, to determine the key aspects that generate better levels of enterprise activity, and to suggest public policies that improve the entrepreneur initiative of countries. Doing Business, by the World Bank, carried out initially in 2002, has the main goal of providing objective information that permits analyzing, understanding, and improving the norms that regulate the enterprise activity to propose reforms that improve the environment for doing business.

The Flash Eurobarometer Survey on Entrepreneurship is a research published since 2000 and it is funded by the European Commission. Its principal aim is to support policy makers in the European Union to understand the problems and to propose feasible solutions. It has coverage over the Member States of the region, besides other nations, like the United States, Norway, Iceland, Brazil, Israel, India, and Russia, among others. With this focus, the GUESSS and the OI2E2 seek to understand the principal aspects of El and of the enterprise activity of university students from distinct countries, which allows their comparing time and place among different 
universities with different approaches.

The GEDI was created to generate a more complete comprehension of economic development by capturing valuable information from the context related with the formation, expansion, and growth of enterprises. It is an annual index that measures the health of entrepreneurship ecosystems in each of the 137 countries where it is developed. The Entrepreneur Development Program (PRODEM) by Universidad General Sarmiento in Argentina makes two measurements, namely, the Index of Systemic Conditions for Dynamic Entrepreneurship (ISCDE-PRODEM) and the Index of Systemic Conditions for Entrepreneurship in Cities (ICECPRODEM). The ISCDE-PRODEM, in the first place, is a tool that permits identifying the most important conditions for the emergence and development of entrepreneurs and dynamic enterprises in a given country. Currently, this index is applied in 60 countries around the world of which 15 are from Latin America.

In the second place, the PRODEM developed the ICEC-PRODEM, which analyzes ecosystems at sub-national level and it compares with similar cities or others of greater development. This index has special application in several Argentine cities (Kantis et al. 2017) and it works with 11 dimensions grouped into four axes that encompass distinct cultural, social, economic, political, and regulatory factors that determine the entrepreneurial potential of a given city. Finally, the Index of Alliance for Entrepreneurship and Innovation (AEI) uses 60 indicators classified into seven groups that have been used by diverse authors to study the entrepreneurial ecosystem, which are, namely: human talent, policy and regulatory framework, market, innovation, support and advisory, culture and funding.

In spite of the varied range of institutions that create entrepreneurship indices in different countries globally, it is evidenced that these analyze nations and cities, but no index has been found that permits examining individuals. The objective of this work was precisely to fill this gap that exists in the specialized literature to construct a multidimensional indicator that groups the individual's initial endowments and the characteristics of the environment.

Considering the aforementioned, although a broad set of indicators exists, as well as methodological approaches to measure El, some gaps still remain from the empirical and theoretical point of view on the role played by institutional and macroeconomic elements over El. Additionally, for the Colombian case, the empirical evidence on the differences at city level in terms of the elements influencing upon El are scarce. In this sense, according to Bird and Jelinek (1989), there are two general determinants of El, the individual and the context, and $\mathrm{EI}$ is the bridge between these two elements.

First, regarding the impact of the enterprise capacity perceived in $\mathrm{El}$, it is indicated that it is enhanced when there is a greater degree of regional social legitimacy. This implies that a local cultural environment that supports the entrepreneurial spirit results particularly relevant to strengthen an individual's perception of feeling capable of creating a successful business. According to Kallas (2019), a higher satisfaction with the external environment and a high level of preparation lead to greater El; however, high levels of regional social legitimacy for enterprise initiative do not always promote the transformation of El into concrete actions (Kibler et al. 2014).

Thus, when the regions show high levels of regional product, high growth of such, a high proportion of people between 25 and 44 years of age, and low levels of enterprise activity, the positive impact of El is weakened because the entrepreneurial behavior enjoys a high degree of regional social legitimacy. The high costs of opportunity of the enterprise initiative seem to undermine the positive effects of the high regional social legitimacy (Kibler et al. 2014). Furthermore, culture, as one of the conditioners of subjective norms, is closely related with the pressures generated by the social, economic, and political environment of each region (Dos 
Santos Souza and Silveira 2018).

Hence, from the empirical evidence emerges consensus in relation with the gender role in developing the entrepreneurial intention. In the available literature, men consistently exhibit more favorable El than women (Tarapuez et al. 2018b, López-Delgado et al. 2019, Nowiński et al. 2019).

Ahmed et al. (2017) conclude that women, in particular, persist to a lesser extent against entrepreneurial training programs; this is more consistent in women without work experience. To complement, Maes et al. (2014) assume that gender differences find their explanation in cognitive, personal, and contextual discrepancies.

Regarding work experience, research is coherent in the definition of an orientation toward the enterprise initiative of those individuals with background in some enterprise activity. For Fatoki (2014) and Solimano (2014), work experience is one of the demographic factors that support the explanation of El. According to Tarapuez-Chamorro et al. (2018), people with an entrepreneurial friend or relative and with over 10 years of work experience show higher probabilities of developing El. Prior experience, whether employed or as entrepreneur, represents a significant source of entrepreneurial self-efficacy (Dehghanpour Farashah 2015).

Similarly, the research by Yi (2018) concludes that the peculiarities of prior work of individuals can improve the entrepreneurial convenience and viability and, in turn, trigger their EI. The findings of other studies show a positive relation of the work experience of individuals with their plans of creating a business (Azanza Martínez De Luco and Campos Granados 2014, Martínez 2016, Tarapuez et al. 2018a). Further, some studies find a statistically significant relation between work experience and the entrepreneurial intention of people (Miranda et al. 2017, Hossain et al. 2019).

In general, empirical findings demonstrate that exposure to a role model (entrepreneurial friends and relatives) represents a significant source of entrepreneurial self-efficacy and perceived behavioral control that promotes the desire of young individuals to create new productive units (Nesse and Bhatta 2017, Loi 2018, Tarapuez-Chamorro et al. 2018, Tarapuez et al. 2018b), which also impacts upon the development of greater El (Tarapuez et al. 2018a) and on the plans to initiate a new business in the following two to three years (Popescu et al. 2014). Specifically, for Kilonzo and Nyambegera (2014), the social norms related with the approval by friends to create a business constitute the substantial relation of El.

Different studies agree that the role of entrepreneurial parents or self-employed parents or having entrepreneurial relatives or having a role model are factors linked to the expectation of an entrepreneurial career (Mayhew et al. 2016, Tarapuez et al. 2018a, Palmer et al. 2019). In this sense, according to Kibler et al. (2014), when individuals get approval and support for the enterprise activity from their close social environment, they consider it less necessary to seek approval from the local environment to develop their El; in this situation, the influence of the regional social legitimacy tends to be insignificant.

The family, then, acts as a fundamental institution that promotes the business spirit by providing resources, social capital, and the promotion of positive attitudes (Campopiano et al. 2016, Liguori et al. 2018). Likewise, the available literature indicates that the presence of entrepreneurs within the family impacts remarkably on the El of the individuals (Campopiano et al. 2016, Haddad 2017, Echeverri-Sánchez et al. 2018, Escolar-Llamazares et al. 2019).

Generally, Meoli et al. (2020) conclude that the immediate context, that is, the influence of relevant people in the lives of the individuals is related with the creation of new ventures. More 
specifically, Wang et al. (2018) found that the economic rewards perceived by the parents have a positive relation with El and that it is partially involved with business self-efficacy. For their part, Morales-Alonso et al. (2016) evidenced that entrepreneurial parents promote El and the attitudes of entrepreneurs in their children. Similarly, Criaco et al. (2017) also found that parental support for their descendants drives IE, but - additionally - said support improves the perceived business convenience and viability, although reducing the desirability by the descendants.

\section{Methodology}

\section{Empirical strategy}

According to Da Motta Jafelice et al. (2012), the Fuzzy theory can be expressed through a fuzzy subset, ${ }^{A}$, from a universe, $X$, composed by students, ${ }^{x_{\mathfrak{i}}}$, with ${ }^{i=1}=1_{x \cdots s} n_{x}$ which have a vector of $j$ attributes or characteristics so that $j=1_{x=s} n_{2}$. Following Bedoya Ospina and Galvis Ciro (2015), that fuzzy subset, ${ }^{A}$, is defined in terms of a membership function, ${ }_{A}$, which can take values in the interval $[0,1]$. Thus, ${ }^{A}$ can be expressed as:

$A=\left\{\left[\mu_{A}(x), x\right] / x \in X\right\}(1)$

Equation (1) indicates that ${ }^{x_{\mathrm{i}}}$ has $100 \%$ membership to the set if $\mu_{A}\left(x_{i j}\right)=1$. In this case, it is confirmed that individual ${ }^{i}$ has no privation from attribute ${ }^{j}$. On the contrary, if $\mu_{A}\left(x_{i j}\right)=0$, it is stated that individual ${ }^{i}$ is totally deprived from attribute $\bar{f}$ or has $0 \%$ degree of membership. Intermediate values must comply with $\mu_{A}\left(x_{i j}\right) \in\left(0_{s} 1\right)$; in this case, individual ${ }^{i}$ is partially deprived from attribute $\tilde{i}$. Regarding El, the fuzzy system leads each MBA student to have a propensity for entrepreneurship, which is located in a degree between $[0,1]$. Based on the proposal by Cheli and Lemmi (1995), the membership function is expressed in equation (2):

(2)

$$
\mu_{A}\left(x_{i j}\right)=\mu_{A}\left(x_{j}^{(k)}\right)=\left\{\begin{array}{c}
0 \text { if } x_{i j}=x_{j}^{k} k=1 \\
\mu_{A}\left(x_{j}^{(k-1)}\right)+\frac{F\left(x_{j}^{k}\right)-F\left(x_{j}^{k-13}\right)}{1-F\left(x_{j}^{k}\right)} \text { if } x_{i j}=x_{j}^{k}, k>1 \\
1 \text { if } x_{i j}=x_{j}^{k} k=K
\end{array}\right.
$$

Where ${ }^{k=1_{x_{x}} K}$, refers to each dimension of attribute $f$ and - in turn - represents the risk of privation in each of the categories of variable ${ }^{i}$; with the aforementioned, in the El analysis, $K$ denotes the best situation with respect to the attribute. By following Cheli and Lemmi (1995), ${ }^{E\left(x_{j}\right)}$ represents the accumulated distribution of attribute ${ }^{\tilde{l}}$ classified according to $k$ 
In turn, according to Gómez et al. (2015), the assignment of the weight of each variable is defined in equation 3 :

$$
W_{j}=\ln \left[\frac{1}{\frac{1}{2} \sum_{1=-1}^{p i n} \mu_{A}\left(x_{2 j}\right)}\right]
$$

Where ${ }^{\sum_{\mathrm{i}=1}^{n} \mu_{A}\left(x_{\mathrm{ij}}\right)}$ denotes the fuzzy proportion of students with $\mathrm{El}$ in reference with attribute $\tilde{i}$. Finally, for the MBA students, given the weights, $w_{j}$ of each variable $\tilde{i}$, the MIEI is given in equation 4 , where ${ }^{T}$ indicates the total of dimensions included in the index:

$$
M I E I_{i}=\frac{\sum_{j-1}^{T} \mu_{A}\left(x_{t j}\right) w_{f}}{\sum_{j=1}^{T} W_{f}} * 100
$$

To obtain a higher level of generality in calculating the MIEI, the following exposes a simulation for eight individuals from the consideration of four attributes related with El. In particular, the attributes and their respective categorization are shown in Table 1.

Definition of attributes and categories

Table 1

\begin{tabular}{|c|l|c|c|c|c|}
\hline & \multicolumn{1}{|c|}{ Attribute } & $\mathbf{1}$ & $\mathbf{2}$ & $\mathbf{3}$ & $\mathbf{4}$ \\
\hline $\mathbf{1}$ & $\begin{array}{l}\text { Entrepreneurial } \\
\text { Intention }\end{array}$ & No, never & Yes, vaguely & $\begin{array}{c}\text { Yes, } \\
\text { seriously }\end{array}$ & $\begin{array}{c}\text { I already have } \\
\text { a business }\end{array}$ \\
\hline $\mathbf{2}$ & Work experience & $>30$ years & $21-30$ years & $<10$ years & $10-20$ years \\
\hline $\mathbf{3}$ & Doing Business & Low & Medium & High & \\
\hline $\mathbf{4}$ & Tax burden & High & Medium & Low & \\
\hline
\end{tabular}

Source: elaborated by the authors

According with the simulation exercise, students revealing higher El are represented in those who already have a business, have work experience between 10 and 20 years, live in a city with high ease of doing business, and where the tax burden is low. In this case, according to Table 2, student number 6 gathers the ideal characteristics and because of this, the MIEI value is 100 .

Data

The database used to run the estimations is a cross-sectional type and it was constructed from primary information and complemented with competitiveness indicators from the Private Competitiveness Council of Colombia. Thus, the construction of the MIEI analyzed students from attendance to programs of the Master's in Business Administration in Colombia; from a total of 54 Master's programs located in 15 cities in the country in 2016, information was obtained from students in 36 programs distributed in 14 cities. The information was collected during the first semester of 2016.

Particularly, data on competiveness, institutions, and fiscal burden from Table 3 are drawn from the Departmental Competitiveness Index (DCl) elaborated by Colombia's Private Competitiveness Council (PCC). It describes the dimensions and variables included in the 
MIEl. However, the microeconomic variables of the individual are taken from the instrument previously validated by Tarapuez Chamorro (2015).

MIEI simulation

Table 2

\begin{tabular}{|c|c|c|c|c|c|c|c|c|c|c|c|c|c|}
\hline \multicolumn{7}{|c|}{ Attribute } & \multicolumn{5}{c|}{ Membership } & \multicolumn{4}{c|}{ Weights } & MIEI \\
\hline ID & $\mathbf{1}$ & $\mathbf{2}$ & $\mathbf{3}$ & $\mathbf{4}$ & $\boldsymbol{\mu}_{A}(\mathbf{1})$ & $\boldsymbol{\mu}_{A}(\mathbf{2})$ & $\boldsymbol{\mu}_{A}(\mathbf{3}$ & $\boldsymbol{\mu}_{A}(\mathbf{4})$ & $W(\mathbf{1})$ & $W(\mathbf{2})$ & $W(\mathbf{3})$ & $\boldsymbol{W}(\mathbf{4})$ & MIEI $_{i}$ \\
\hline $\mathbf{1}$ & 2 & 3 & 2 & 1 & 0.416 & 0.538 & 0.4 & 0 & 0.693 & 0.619 & 0.51 & 0.60 & 34.02 \\
\hline $\mathbf{2}$ & 2 & 3 & 1 & 2 & 0.416 & 0.538 & 0 & 0.454 & 0.693 & 0.619 & 0.51 & 0.60 & 36.95 \\
\hline $\mathbf{3}$ & 1 & 2 & 3 & 1 & 0 & 0.153 & 1 & 0 & 0.693 & 0.619 & 0.51 & 0.60 & 24.94 \\
\hline $\mathbf{4}$ & 3 & 4 & 1 & 2 & 0.75 & 1 & 0 & 0.454 & 0.693 & 0.619 & 0.51 & 0.60 & 58.22 \\
\hline $\mathbf{5}$ & 4 & 1 & 2 & 3 & 1 & 0 & 0.4 & 1 & 0.693 & 0.619 & 0.51 & 0.60 & 61.89 \\
\hline $\mathbf{6}$ & 4 & 4 & 3 & 3 & 1 & 1 & 1 & 1 & 0.693 & 0.619 & 0.51 & 0.60 & 100 \\
\hline $\mathbf{7}$ & 2 & 3 & 3 & 3 & 0.416 & 0.538 & 1 & 1 & 0.693 & 0.619 & 0.51 & 0.60 & 71.59 \\
\hline $\mathbf{8}$ & 1 & 3 & 3 & 2 & 0 & 0.538 & 1 & 0.454 & 0.693 & 0.619 & 0.51 & 0.60 & 46.09 \\
\hline
\end{tabular}

Source: elaborated by the authors, based on Gómez et al. (2015)

Table 3

MIEI Dimensions and variables

\begin{tabular}{|c|l|l|}
\hline Dimension & \multicolumn{1}{|c|}{ Variable } & \multicolumn{1}{c|}{ Source } \\
\hline Entrepreneurial Intention & Entrepreneurial Intention & Tarapuez Chamorro (2015) \\
\hline \multirow{4}{*}{$\begin{array}{c}\text { Socio-demographic } \\
\text { conditions }\end{array}$} & Work experience & Tarapuez Chamorro (2015) \\
\cline { 2 - 3 } Family aspects & Marital status & Tarapuez Chamorro (2015) \\
\hline \multirow{4}{*}{$\begin{array}{c}\text { Institutional or } \\
\text { environmental conditions }\end{array}$} & Father's formation & Tarapuez Chamorro (2015) \\
\cline { 2 - 3 } & Mother's formation & Tarapuez Chamorro (2015) \\
\cline { 2 - 3 } & Father's occupation & Tarapuez Chamorro (2015) \\
\cline { 2 - 3 } & Mother's occupation & Tarapuez Chamorro (2015) \\
\cline { 2 - 3 } & Ease of doing business & PCC $^{*}$ \\
\cline { 2 - 3 } & Tax burden & PCC $^{*}$ \\
\cline { 2 - 3 } & Unemployment rate & PCC $^{*}$ \\
\cline { 2 - 3 } & $\begin{array}{l}\text { Number of tax payments per } \\
\text { year }\end{array}$ & PCC $^{*}$ \\
\hline Socioeconomic conditions & Economic strata (social class) & Tarapuez Chamorro (2015) \\
\hline
\end{tabular}

* Private Competitiveness Council of Colombia

** National Administrative Department on Statistics of Colombia

Source: elaborated by the authors

\section{Results}

Given the weight of the dimensions included in the MIEI calculation, those related with family aspects and institutional or environmental conditions reflect higher importance in the index. In this respect, the literature on El supports these estimations; in particular, a statistically significant relationship has been documented between the influence of the family and $\mathrm{El}$ 
(Nesse and Bhatta 2017, Tarapuez-Chamorro et al. 2018, Tarapuez et al. 2018b). Likewise, regarding the second dimension in relevance, Kallas (2019) presents empirical evidence on the influence of the environment on business initiatives.

In turn, in the analysis by variable, the tax burden, the unemployment rate, and aspects related with the father's and mother's occupation report the major weighing in the estimations. According to the methodology of fuzzy indicators, this fact implies that, in relation with these variables, a higher density of students are in a situation of privation of the attribute; that is, in general, MBA students are undertaking their graduate studies in cities with a high tax burden, as well as an important density of individuals are in cities with unemployment rates above the national median. In consideration, $45 \%$ of the students reside in cities with unemployment rates above $9.21 \%$ (median of the 14 cities analyzed).

By virtue of the results of the MIEI and according to that illustrated in Table 4, it is inferred that MBA students in Colombia have - on average - relatively moderate MIEI, with a median of 58.36 from a total of 100 possible points. In the analysis of the behavior of the index, it is interesting to note that in the range of the data, the maximum value estimated is 89.16 . The standard deviation denotes a low dispersion of the analyzed dataset. In this logic, Fig. 1 presents a normalized distribution, which evidences a significant number of students with medium levels in the MIEl; in contrast, few observations are noticed in the tails of the distribution.

Table 4

MIEI descriptive statistics

\begin{tabular}{|c|c|c|c|c|c|}
\hline Variable & Observations & Median & Standard deviation & Minimum & Maximum \\
\hline $\mathrm{MIEI}$ & 477 & 58.36 & 12.61 & 23.81 & 89.16 \\
\hline
\end{tabular}

Source: elaborated by the authors

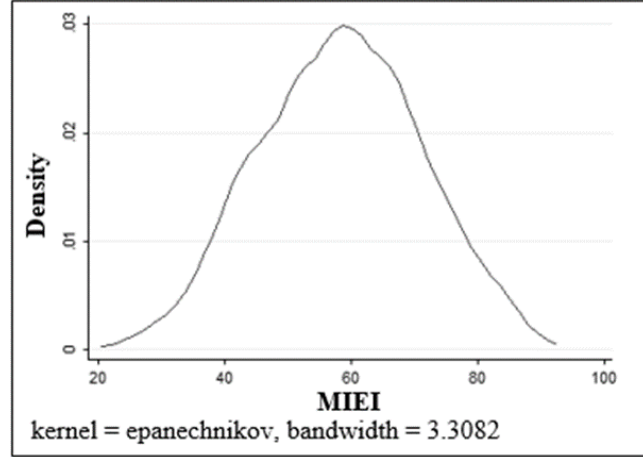

Fig. 1 - MIEI distribution Source: elaborated by the authors

Fig. 2 - MIEI by cities Source: elaborated by the authors

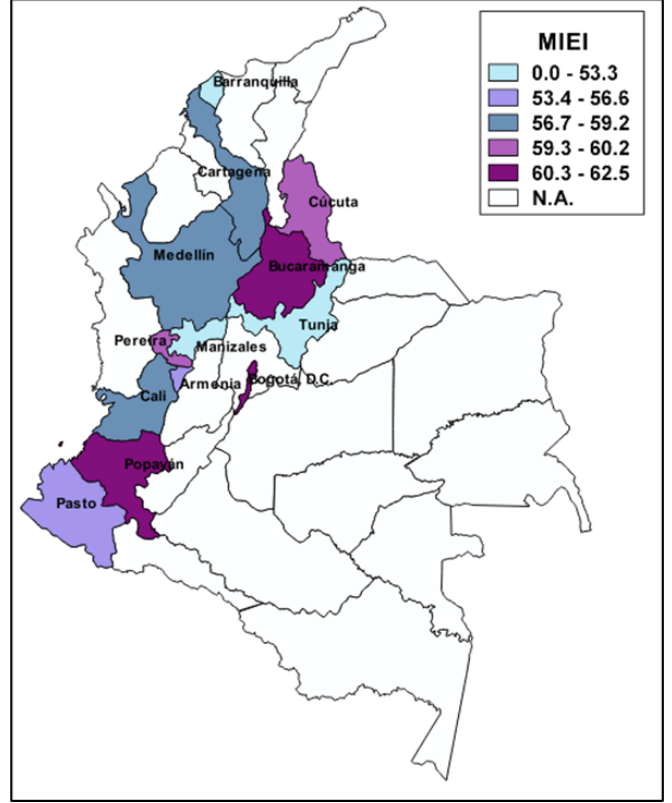


In addition, the MIEI calculation is intervened by institutional arrangements specific to the environment or the city. Particularly, this is due to the characteristics of the labor market or to its structure and size. With this in mind, the MIEI decomposition among the 14 cities analyzed permits evidencing, from an exploratory analysis, spatial heterogeneity in the index (Fig. 2), with Bogotá, D.C., Popayán, and Bucaramanga being the cities with the highest median rates of El, unlike Tunja, which lags behind in the indicator.

The research results are consistent with the Global Entrepreneurship Monitor Colombia (2019) study in which the capital city has a rate of enterprise activity (REA) higher than that of the country. Added to this, Bogotá, D.C., is the zone with the country's highest GDP per capita and, in this regard, it may be inferred that entrepreneurship in this city is of higher quality than in the rest of Colombia. For Popayán (Cauca), the El index is explained by the fiscal structure that contemplates the number of tax payments per year compared with the rest of the studied cities.

The effect of taxes on El has the appropriate result from the empirical evidence, given that a high tax structure indicates a reduced enterprise initiative. Entrepreneurs face national taxes that excise the utilities of companies, which - for our case - reach $33 \%$, with possibilities of lowering according to the dynamics of the tributary reform. In case of not invoicing due to not generating income from the operation, the presumptive income tax is applied, which rises to $3.5 \%$ of the legally constituted assets. Furthermore, and according to the company's city of operation, the local Industry, Commerce, and Tourism tax must be paid, which can be in the range from 5 to 10 per thousand of the total sales. Once the business is formally registered, the costs associated with the tax scheme are incorporated onto the general structure of costs, with which the entrepreneur is obligated to increase the level of income to compensate the expected benefit. That is a critical situation during a consolidation phase of the business initiative. Regions with a higher tax burden will have lower indices of business initiative. In contrast, the city of Tunja (Boyacá) occupies the last place in Colombia in reference to the ease of creating businesses, a situation that explains its lowest MIEI.

Moreover, the results show a small difference in the MIEI of men and women, that is, male MBA students may have a greater probability for entrepreneurship than the females. Various investigations related with the theme also found positive differences toward the males (Azanza Martínez De Luco and Campos Granados 2014, Bergmann et al. 2018, Lechner et al. 2018, Thornton and Klyver 2019). The cause for this situation may lie in the difference of individual characteristics and in the specific peculiarities of each country that favor the development of male ventures, particularly (Afandi and Kermani 2015, IIman et al. 2020). This situation can be explained by the presence of implicit barriers to El development in the female population (Miranda et al. 2017), which is why women might show a lower propensity for business creation (Muñoz-Fernández et al. 2016, Van Dijk 2020) within a context whose peculiarities can be based on the paternalist structure prevalent in some societies (Tarapuez-Chamorro et al. 2018). According to the results of this study, men have a higher index by six points than women.

In this sense, it is fitting to mention that gender differences constitute the most-frequent research theme in the study of $\mathrm{EI}$. On the matter, the initial findings are preserved about men having higher El than women (Liñán and Fayolle 2015), although explicative/descriptive approaches or conventional quantitative methods have been adopted, which limit comprehending gender specificities and the complexity of women's entrepreneurial barriers (Wu et al. 2019).

Additionally, age (Fig. 3) constitutes a poorly explored area in entrepreneurial research; however, pioneering studies about its relation with El were conducted in the 1980s; these 
indicate that the said variable is an important factor to determine the propensity of individuals to starting a company (Brockhaus 1982). Currently, the findings are not conclusive, given that distinct results are found about El throughout the vital cycle. On the one hand, some works evidence a direct relationship between age and El (Tarapuez et al. 2018a), while others estimate an inverse relationship (Tsai et al. 2016; Bohlmann et al. 2017). On the other hand, Halvorsen and Morrow-Howell (2017) show that older adults have a higher rate of selfemployment than younger adults. In similar findings, Thorgren et al. (2016) report that the effect of age on starting a business, indicates an inverted $U$ relationship. In this line, Minola et al. (2016) evidence that some values that can influence El increase during adulthood, show a maximum during middle adult age, and diminish notably during late adulthood.

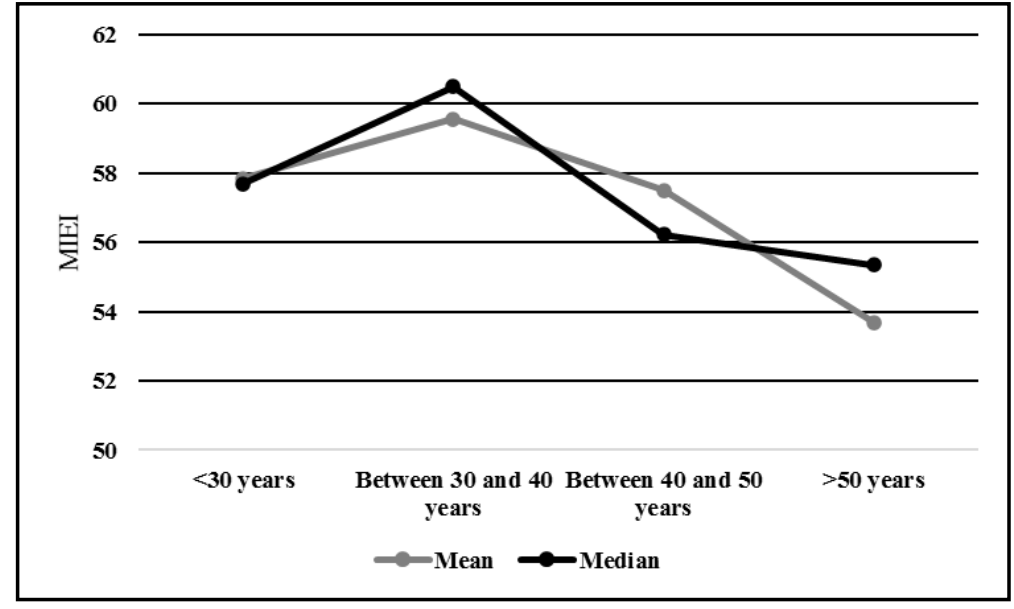

Fig. 3 - MIEl by age range

Source: elaborated by the authors

Within this context, a higher MIEI value is observed for ages between 30 and 40 years; a decreasing trend is noted as of 40 years of age and on. On the discussion of the results, Tsai et al. (2016), Bohlmann et al. (2017), and Gielnik et al. (2018), among others, show that age is related negatively with the enterprise activity. Contrary ideas are documented in Halvorsen and Morrow-Howell (2017), who evidence that older adults have higher rates of self-employment than their younger counterparts; this logic is also reported by Tarapuez et al. (2018a). In addition, the minimum difference between the mean and the median reflects symmetry in the data, which is evident in Fig. 3 and it corroborates the normalized distribution from Fig. 1.

By area of studies, the faculties of engineering and health sciences occupy the first places in relation to MIEI (Fig. 4). Economic sciences and agricultural sciences were in the lowest places of El during the analysis period. Similar results are documented by Azanza Martínez De Luco and Campos Granados (2014), who found greater El in the faculties of engineering and law in a case applied for Universidad de Deusto in Spain. Likewise, recent international evidence was found in the work by Krauss-Delorme et al. (2018), who found no statistically significant evidence in $\mathrm{El}$ among the students from health sciences and the rest of the faculties, for the Uruguayan case. 


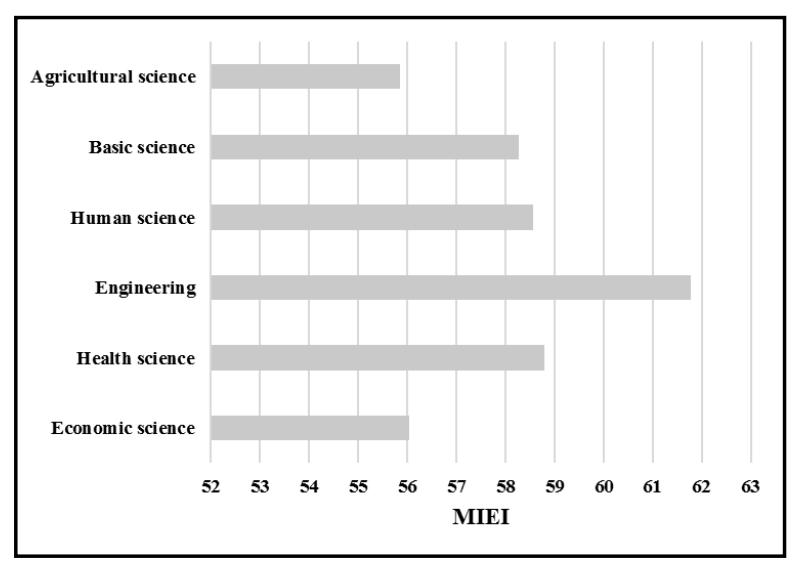

Fig. 4 - MIEI by study area

Source: elaborated by the authors

\section{Discussion}

The empirical evidence exposed in this paper in relation to heterogeneity in El in Colombian students has been documented in various related studies. Thus, Adamson and Varela (2016), using a model with panel data, document the regional differences in El for 52 countries. Gumbau Albert (2017) documents regional heterogeneity in El among Spanish regions, attributing to it the disparities in economic growth. Similar findings are presented by Shacheendran and Mathew (2017), who - in a case applied for Hindu regions - conclude that upon the same institutions, the El process does not emerge uniformly.

Some works conclude that individuals from certain university careers have superior El. For Azanza Martínez De Luco and Campos Granados (2014), people who study engineering and law have higher El levels, while for Van Dijk (2020), individuals studying business, economics, and law have greater El. For Birdthistle (2006), entrepreneurs emerge more from areas of engineering, sciences, and other technical disciplines than from studies in commerce and business. Ruiz Navarro et al. (2008) conclude that students from the area of economy and enterprise show more El. In spite of these findings, other studies, like that by Ramos et al. (2020), do not provide satisfactory results to permit confirming the influence of professional formation on the individuals' entrepreneurial plans.

With other results, Stuetzer et al. (2018) - from an approach based on causal relations capture clusters of metropolitan areas around EI and the dynamics of the labor market; thus, evidencing the spatial groupings of regions with better employment indices and a higher EI. In this line of findings, Espinoza et al. (2019) suggest, for the Chilean case, that regions with higher levels of business culture tend to have a greater employment growth. For Fleck et al. (2020), the statistical analyses reveal sound correlations among various business concepts and national cultural indices in an intra-regional study for 400 universities distributed in 70 countries.

The document introduces and validates a methodology supported by the fuzzy logic sets as strategy to measure El. Thus, the indicator proposed is flexible in considering variables from different levels that impact upon entrepreneurial decisions. Thereby, in light of the findings, the 
research results will guide public policy makers whose objective is entrepreneurship stimulus with regional focus. Thus, the design of public policies to promote the entrepreneur spirit implies the recognition of cultural, economic, and family contexts; moreover, strategies must be based on comprehensive, permanent, and articulated policies.

Furthermore, although the research results are robust in relation with other indices used in the literature to measure entrepreneurial capacity, the number of observations used constitutes a sensitive point of the document, although it was possible to cover an important number of cities in Colombia. Consequently, new research should emerge under the optics of fuzzy sets, incorporating different analysis units and annexing a higher number of variables that capture the institutional and economic performance of the regions to document intra-regional heterogeneity in terms of entrepreneurial capacity.

\section{Conclusions}

As a result of the information presented, it is feasible to state that El studies in Colombia require more precise and sensitive indicators that account for the conditions of the environment beyond the differences in the individuals' endowments. With this gap in the literature, this document analyzes El through a multidimensional fuzzy indicator applied to MBA students in Colombia, comparing the results by cities, gender, age, and study area.

From the obtained results, additional elements are identified to understand the nature of El in Colombia. It is emphasized that - on average - El is moderate, while no big gender differences are observed. To continue, the MIEI is higher for students between 30 and 40 years of age and whose undergraduate academic formation corresponds to the area of engineering, which agrees with the expectations with respect to these variables. The second key element is how multidimensionality in evaluating MIEI permits identifying EI matrices among cities. In that sense, the most significant variable in the institutional context is the tax burden; this is based on a more robust assessment of the environment's influence on the students' business initiatives. With this in mind, it is concluded that contextual factors can discourage individuals with high levels of El.

Third, the results also highlight the existence of a cycle in which MBA students between 30 and 40 years of age show a higher El. The MIEI seems to increase from 20 to 40 years of age to then diminish. By extrapolating these findings, the prior results imply that, on average, more adult individuals reveal lower probabilities of developing El. The explanation for these findings may be related with the phenomenon that upon entering the job market at an early age, students have low knowledge and business skills; thus, as age accumulates, entrepreneurial plans increase, reaching a peak at middle adult age.

In addition, it is preponderant to highlight that, in the analysis by study area, the highest MIEI is obtained in the area of engineering. The aforementioned permits conjecturing that soon we may foresee the creation of new technologically based enterprises, necessary to promote economic convergence and employment. Finally, although the results of the fuzzy logic-based methodology is robust in the sense that it includes factors that control fixed effects specific to each city, future research should include new institutional arrangements that modify incentives to undertake entrepreneurial activity. Furthermore, it is pertinent to extrapolate the methodology to different population segments to guarantee the validity of the estimations.

\section{References}

ADAMSON M., VARELA F. (2016), Revisitando a Schumpeter y al emprendedor: Consideraciones para Costa Rica, Universidad de Costa Rica, San José, C.R. AFANDI E., KERMANI M. (2015), Bridging the Gender Gap in Entrepreneurship: An 
Empirical Analysis, Journal of Developmental Entrepreneurship 20 (2), 1550008.

AHMED T., CHANDRAN V. G. R., KLOBAS J. E. (2017), Demographic differences in learner response to entrepreneurial education programmes in Pakistan, Educational Studies 43 (4), 464-483.

AZANZA MARTÍNEZ DE LUCO G., CAMPOS GRANADOS J. A. (2014), La intención emprendedora en estudiantes universitarios: el caso de la Universidad de Deusto, Boletín de Estudios Económicos 69 (211), 151-172.

BARBA-SÁNCHEZ V., ATIENZA-SAHUQUILLO C. (2017), Entrepreneurial intention among engineering students: The role of entrepreneurship education, European Research on Management and Business Economics 24 (1), 53-61.

BAUM J. R., FRESE M., BARON R. A., KATZ J. A. (2007), Entrepreneurship as an Area of Psychology Study: An Introduction, in: Baum J. R., Frese M., Baron R. A. (eds.), The Psychology of Entrepreneurship, Psychology Press, New York, pp. 1-18.

BEDOYA OSPINA J. G., GALVIS CIRO J. C. (2015), Una aplicación de la teoría fuzzy al análisis de la pobreza en Antioquia, Ensayos de Economía 25 (47), 127-150.

BERGMANN H., GEISSLER M., HUNDT C., GRAVE B. (2018), The climate for entrepreneurship at higher education institutions, Research Policy 47 (4), 700-716.

BIRD B. (1988), Implementing entrepreneurial ideas: the case for intention, The Academy of Management Review 13 (3), 442-453.

BIRD B., JELINEK M. (1989), The Operation of Entrepreneurial Intentions, Entrepreneurship Theory and Practice 13 (2), 21-30.

BIRDTHISTLE N. (2006), Profiling the entrepreneur: an examination of entrepreneurs in the mid-west region of Ireland, Journal of Economics and Organisation of Enterprise 7 (678), 74-83.

BOHLMANN C., RAUCH A., ZACHER H. (2017), A lifespan perspective on entrepreneurship: Perceived opportunities and skills explain the negative association between age and entrepreneurial activity, Frontiers in Psychology 8, 2015.

BROCKHAUS R. (1982), The Psychology of Entrepreneurship, in: Kent C. A., Sexton D. L., Vesper K. H. (eds.), Encyclopedia of Entrepreneurship, Prentice-Hall, Englewood Cliffs, NJ.

CAMPOPIANO G., MINOLA T., SAINAGHI R. (2016), Students climbing the entrepreneurial ladder: Family social capital and environment-related motives in hospitality and tourism, International Journal of Contemporary Hospitality Management 28 (6), 1115-1136.

CHELI B., LEMMI A. (1995), A "totally" fuzzy and relative approach to the multidimensional analysis of poverty, Economic Notes 24 (1), 115-134.

CHENG C.-F., CHANG M.-L., LI C.-S. (2013), Configural paths to successful product innovation, Journal of Business Research 66 (12), 2561-2573.

COVIN J. G., EGGERS F., KRAUS S., CHENG C.-F., CHANG M.-L. (2016), Marketingrelated resources and radical innovativeness in family and non-family firms: A configurational approach, Journal of Business Research 69 (12), 5620-5627.

CRIACO G., SIEGER P., WENNBERG K., CHIRICO F., MINOLA T. (2017), Parents' performance in entrepreneurship as a "double-edged sword" for the intergenerational transmission of entrepreneurship, Small Business Economics 49, 841-864.

DA MOTTA JAFELICE R. S., CARVALHO DE BARROS L., BASSANEZI R. C. (2012), Teoria dos Conjuntos Fuzzy com Aplicações, Sociedade Brasileira de Matemática Aplicada e Computacional, São Carlos, SP.

DEHGHANPOUR FARASHAH A. (2015), The effects of demographic, cognitive and institutional factors on development of entrepreneurial intention: Toward a socio-cognitive model of entrepreneurial career, Journal of International Entrepreneurship 13, 452-476.

DOS SANTOS SOUZA R., SILVEIRA A. (2018), Intención emprendedora en contexto universitario brasileño, Revista Gestão Universitária na América Latina - GUAL 11 (2), 297318.

ECHEVERRI-SÁNCHEZ L., VALENCIA-ARIAS A., BENJUMEA-ARIAS M., BARRERADEL TORO A. (2018), Factores que inciden en la intención emprendedora del estudiantado 
universitario: Un análisis cualitativo, Revista Electrónica Educare 22 (2), 1-19.

ESCOLAR-LLAMAZARES M. C., LUIS-RICO I., DE LA TORRE-CRUZ T., HERRERO Á., JIMÉNEZ A., PALMERO-CÁMARA C., JIMÉNEZ-EGUIZÁBAL A. (2019), The Socioeducational, Psychological and Family-Related Antecedents of Entrepreneurial Intentions among Spanish Youth, Sustainability 11 (5), 1252.

ESPINOZA C., MARDONES C., SÁEZ K., CATALÁN P. (2019), Entrepreneurship and regional dynamics: the case of Chile, Entrepreneurship \& Regional Development 31 (9-10), 755 $-767$.

FATOKI O. (2014), The entrepreneurial intention of undergraduate students in South Africa: the influences of entrepreneurship education and previous work experience, Mediterranean Journal of Social Sciences 5 (7), 294-299.

FERREIRA J. J. M., FERNANDES C. I., KRAUS S. (2019), Entrepreneurship research: mapping intellectual structures and research trends, Review of Managerial Science 13, 181205.

FLECK E., KAKOURIS A., WINKEL D. (2020), Cultural traits of entrepreneurship education: a cross-national study, Journal of Entrepreneurship in Emerging Economies, aheadof-print.

GIELNIK M. M., ZACHER H., WANG M. (2018), Age in the entrepreneurial process: The role of future time perspective and prior entrepreneurial experience, Journal of Applied Psychology 103 (10), 1067-1085.

GLOBAL ENTREPRENEURSHIP MONITOR COLOMBIA (2019), GEM COLOMBIA Estudio de la actividad empresarial en 2017, Editorial Universidad del Norte, Barranquilla.

GÓMEZ M. S., GALVIS-APONTE L. A., ROYUELA V. (2015), Calidad de vida laboral en Colombia: un índice multidimensional difuso, Banco de la República. Centro de Estudios Económicos Regionales, Cartagena.

GUMBAU ALBERT M. (2017), Entrepreneurship, innovation and regional performance: application for the Spanish regions, Entrepreneurship \& Regional Development 29 (3-4), 271 291.

HADDAD G. J. (2017), Understanding women entrepreneurial motivations: Does age matter?, in: Bassil Sleilati E. (ed.), Lebanon: Social, Political and Economic Issues, Nova, New York, pp. 65-84.

HALVORSEN C. J., MORROW-HOWELL N. (2017), A conceptual framework on selfemployment in later life: toward a research agenda, Work, Aging and Retirement 3 (4), 313324.

HOSSAIN U., AL ASHEQ A., ARIFUZZAMAN S. M. (2019), Entrepreneurial intention of Bangladeshi students: impact of individual and contextual factors, Problems and Perspectives in Management 17 (4), 493-503.

ILMAN A. H., ANANDA N. A., POHAN A. S. (2020), Entrepreneurial Education and University Environment toward Students Entrepreneurial Intention, International Journal of Innovative Science and Research Technology 5 (1), 1271-1278.

KALLAS E. (2019), Environment-Readiness Entrepreneurship Intention Model: The Case of Estonians and the Russian-Speaking Minority in Estonia, SAGE Open 9 (1), 1-15.

KANTIS H., FEDERICO J., MENENDEZ C., IBARRA S. (2017), Ciudades para emprender: Estudio diagnóstico de las condiciones de partida del programa - Línea de base cohorte 2016, e Ministerio de Producción de la Nación, Buenos Aires.

KIBLER E., KAUTONEN T., FINK M. (2014), Regional social legitimacy of entrepreneurship: Implications for entrepreneurial intention and start-up behaviour, Regional Studies 48 (6), 995-1015.

KILONZO P. M., NYAMBEGERA S. M. (2014), Determinants of entrepreneurial intention among university business students in Kenya: Lessons from Kenyatta University, International Journal of Entrepreneurship and Small Business 22 (2), 231-250.

KRAUS S., MENSCHING H., CALABRÒ A., CHENG-FENG C., FILSER M. (2016), Family firm internationalization: A configurational approach, Journal of Business Research 69 
(11), 5473-5478.

KRAUS S., RIBEIRO-SORIANO D., SCHÜSSLER M. (2018), Fuzzy-set qualitative comparative analysis (fsQCA) in entrepreneurship and innovation research - the rise of a method, International Entrepreneurship and Management Journal 14, 15-33.

KRAUSS-DELORME C., BONOMO-ODIZZIO A., VOLFOVICZ-LEÓN R. (2018), Modelo predictivo de la intención emprendedora universitaria en Latinoamérica, Journal of Technology Management \& Innovation 13 (4), 84-93.

LECHNER C. M., SORTHEIX F. M., OBSCHONKA M., SALMELA-ARO K. (2018), What drives future business leaders? How work values and gender shape young adults' entrepreneurial and leadership aspirations, Journal of Vocational Behavior 107, 57-70.

LIGUORI E. W., BENDICKSON J. S., MCDOWELL W. C. (2018), Revisiting entrepreneurial intentions: a social cognitive career theory approach, International Entrepreneurship and Management Journal 14, 67-78.

LIÑÁN F., FAYOLLE A. (2015), A systematic literature review on entrepreneurial intentions: citation, thematic analyses, and research agenda, International Entrepreneurship and Management Journal 11, 907-933.

LOI M. (2018), Dynamics of Entrepreneurship Education: How Human and Social Capital Interact with Learning, in: Zakaria N., Kaushal L. A. (eds.), Global Entrepreneurship and New Venture Creation in the Sharing Economy, IGI Global, Hershey, PA, pp. 37-53.

LÓPEZ-DELGADO P., IGLESIAS-SÁNCHEZ P. P., JAMBRINO-MALDONADO C. (2019), Gender and university degree: a new analysis of entrepreneurial intention, Education + Training 61 (7-8), 797-814.

MAES J., LEROY H., SELS L. (2014), Gender differences in entrepreneurial intentions: A TPB multi-group analysis at factor and indicator level, European Management Journal 32 (5), 784-794.

MARTÍNEZ A. (2016), Factores socio-culturales asociados al emprendedor: evidencia empírica para América Latina, Revista Venezolana de Gerencia 21 (74), 312-330.

MAYHEW M. J., SIMONOFF J. S., BAUMOL W. J., SELZNICK B. S., VASSALLO S. J. (2016), Cultivating Innovative Entrepreneurs for the Twenty-First Century: A Study of U.S. and German Students, The Journal of Higher Education 87 (3), 420-455.

MEOLI A., FINI R., SOBRERO M., WIKLUND J. (2020), How entrepreneurial intentions influence entrepreneurial career choices: The moderating influence of social context, Journal of Business Venturing 35 (3), 105982.

MINOLA T., CRIACO G., OBSCHONKA M. (2016), Age, culture, and self-employment motivation, Small Business Economics 46, 187-213.

MIRANDA F. J., CHAMORRO-MERA A., RUBIO S. (2017), Academic entrepreneurship in Spanish universities: An analysis of the determinants of entrepreneurial intention, European Research on Management and Business Economics 23 (2), 113-122.

MORALES-ALONSO G., PABLO-LERCHUNDI I., VARGAS-PEREZ A. M. (2016), An Empirical Study on the Antecedents of Knowledge Intensive Entrepreneurship, International Journal of Innovation and Technology Management 13 (5), 1640011.

MUÑOZ-FERNÁNDEZ G. A., RODRÍGUEZ-GUTIÉRREZ P., SANTOS-ROLDÁN L. (2016), Entrepreneurship in higher education in tourism, gender issue?, Electronic Journal of Research in Educational Psychology 14 (38), 45-66.

NESSE J. G., BHATTA B. P. (2017), The influence of local entrepreneurial environment and role models in motivating youths to create a new enterprise, International Journal of Entrepreneurship and Economic Issues 1 (1), 53-70.

NOWIŃSKI W., YACINE HADDOUD M., LANČARIČ D., EGEROVÁ D., CZEGLÉDI C. (2019), The impact of entrepreneurship education, entrepreneurial self-efficacy and gender on entrepreneurial intentions of university students in the Visegrad countries, Studies in Higher Education 44 (2), 361-379.

OOSTERBEEK H., VAN PRAAG M., IJSSELSTEIN A. (2010), The impact of entrepreneurship education on entrepreneurship skills and motivation, European Economic Review 54 (3), 442-454. 
PALMER C., FASBENDER U., KRAUS S., BIRKNER S., KAILER N. (2019), A chip off the old block? The role of dominance and parental entrepreneurship for entrepreneurial intention, Review of Managerial Science, 1-21.

PENG Z., LU G., KANG H. (2012), Entrepreneurial Intentions and Its Influencing Factors: A Survey of the University Students in Xi'an China, Scientific Research 3 (8B), 95-100.

POPESCU C. C., MAXIM A., DIACONU (MAXIM) L. (2014), Determinants of entrepreneurial intentions among Romanian students, Transformations in Business \& Economics 13 (3C), 370-388.

RAMOS D., MADEIRA M. J., DUARTE F. A. P. (2020), Entrepreneurship Education and Entrepreneurial Intention: The Case of Portugal, Economy of Region 16 (1), 157-170.

RUIZ NAVARRO J., ROJAS VÁZQUEZ A., SUÁREZ LLORENS A. (2008), Actitudes de los estudiantes universitarios de Andalucía ante la creación de empresas, Universidad de Cádiz, Cádiz.

SHACHEENDRAN V., MATHEW T. (2017), Regional differences in growth of entrepreneurship among SC/STS IN MSMEs: a study with reference to northern and southern regions of Kerala, International Journal of Research in Commerce \& Management 8 (5), 35-38.

SOLIMANO A. (2014), Entrepreneurship, the Middle Class, and Social Mobility: An Overview of Literature, in: Lora E., Castellani F. (eds.), Entrepreneurship in Latin America: A Step up the Social Ladder?, The Inter-American Development Bank, The World Bank, Washington, D.C., pp. 17-50.

STUETZER M., AUDRETSCH D. B., OBSCHONKA M., GOSLING S. D., RENTFROW P. J., POTTER J. (2018), Entrepreneurship culture, knowledge spillovers and the growth of regions, Regional Studies 52 (5), 608-618.

TARAPUEZ E., GARCÍA M. D., CASTELLANO N. (2018a), Aspectos socioeconómicos e intención emprendedora en estudiantes universitarios del Quindío (Colombia), Innovar 28 (67), 123-135.

TARAPUEZ E., GUZMÁN DÍAZ B. E., PARRA HERNÁNDEZ R. (2018b), Intención emprendedora y aspectos sociodemográficos en Colombia, Espacios 39 (28), 19-36.

TARAPUEZ CHAMORRO E. (2015), Factores que influyen en las intenciones de creación de empresas de los estudiantes universitarios del Departamento del Quindío (Colombia), Universidad Nacional de Córdoba, Retrieved from: www.rdu.unc.edu.ar.

TARAPUEZ-CHAMORRO E., ARISTIZÁBAL-TAMAYO J. M., MONARD-BLANDÓN C. (2018), Aspectos sociodemográficos y familiares e intención empresarial en estudiantes de Maestría en Administración en Colombia, Estudios Gerenciales 34 (149), 422-434.

THOMPSON E. R. (2009), Individual entrepreneurial intent: Construct clarification and development of an internationally reliable metric, Entrepreneurship Theory and Practice 33 (3), 669-694.

THORGREN S., SIRÉN C., NORDSTRÖM C., WINCENT J. (2016), Hybrid entrepreneurs' second-step choice: The nonlinear relationship between age and intention to enter full-time entrepreneurship, Journal of Business Venturing Insights 5, 14-18.

THORNTON P. H., KLYVER K. (2019), Who is More Likely to Walk the Talk? The Symbolic Management of Entrepreneurial Intentions by Gender and Work Status, Innovation 21 (1), 102-127.

TSAI K.-H., CHANG H.-C., PENG C.-Y. (2016), Refining the linkage between perceived capability and entrepreneurial intention: roles of perceived opportunity, fear of failure, and gender, International Entrepreneurship and Management Journal 12, 1127-1145.

VAN DIJK C. (2020), Entrepreneurial Intention of University Students in The Netherlands, Wageningen University \& Research, Retrieved from: www.library.wur.nl.

WANG D., WANG L., CHEN L. (2018), Unlocking the influence of family business exposure on entrepreneurial intentions, International Entrepreneurship and Management Journal 14, 951-974.

WU J., LI Y., ZHANG D. (2019), Identifying women's entrepreneurial barriers and empowering female entrepreneurship worldwide: a fuzzy-set QCA approach, International 
Entrepreneurship and Management Journal 15, 905-928.

YI G. (2018), Impact of internship quality on entrepreneurial intentions among graduating engineering students of research universities in China, International Entrepreneurship and Management Journal 14, 1071-1087.

Initial submission: 07.04.2020

Revised submission: 21.10 .2020

Final acceptance: 01.12.2020

Correspondence: Faculty of Accounting, Economic and Administrative Sciences, Universidad de Manizales, Cra 9 a \# 19-03 Campo Hermoso, Manizales, Caldas, Colombia.

Email: jm.aristizabal@umanizales.edu.co 
